\title{
METODE PERANCANGAN SISTEM SCADA PADA SISTEM KELISTRIKAN UNTUK MENGHADAPI ERA REVOLUSI INDUSTRI 4.0
}

\author{
Imam Ubedillah $^{1}$ \\ ${ }^{1}$ Prodi teknik elektro,Universitas Islam Kalimantan MAB \\ imamubeddillah@gmail.com
}

\begin{abstract}
Abstrak - Pemantauan dari penggunaan dan penghasilan energi PLTS merupakan salah satu upaya untuk menjaga ketersediaan energi, sehingga penggunaan energi yang berlebihan akan dapat dihindari dan penggunaan energi tersebut akan semakin tepat guna yang diimplementasikan dengan sistem yang mendukung seperti pemantauan, pengkontrolan perangkat dan pengolahan data, pada sistem SCADA (Supervisory Control And Data Acquisition) ini memuat sebuah sistem pengawasan dan pengendalian dengan cara melakukan pengumpulan dan analisa data secara real time dan dapat diakses melalui Komputer. Aplikasi server dibuat dengan programming Visual Basic yang digunakan untuk pemantauan data secara real-time, melakukan pengkontrolan perangkat keras dan data sensor disimpan kedalam database agar dapat menampilkan history data maupun untuk pengolahan data lain.
\end{abstract}

\section{Kata Kunci : PLTS, SCADA, Arduino, SQL Server, Visual Basic}

\section{PENDAHULUAN}

Energi surya terbukti menjadi alternatif dalam hal pengurangan biaya listrik dan keberlanjutan energi. Di sisi lain, sistem tersebut memerlukan perawatan berkala untuk memastikan operasi yang tepat, sehingga pemantauan output energi untuk panel sel surya akan meningkatkan efisiensi keseluruhan sistem. Pemantauan output dari panel individu membantu mengurangi daya yang hilang dari panel sel surya. Pada perancangan sistem SCADA (Supervisory Control and Data Acquisition) berbasis realtime web monitoring sistem dan sistem kontrol untuk mengintegrasikan sistem sel surya, unit baterai, jaringan beban yang menggunakan mikrokontroller arduino. Sistem SCADA menghubungkan ke jaringan internet, dapat memantau dan mengontrol sistem sel surya, baterai dan jaringan beban secara realtime dalam berbagai kondisi operasi. Ditunjang dengan adanya datalogger yang mampu menyimpan semua data parameter operasi dan implementasi data acquisition.

Industri merupakan bidang yang memiliki fungsi dan pengaruh yang sangat vital dalam bidang perekonomian diseluruh dunia. Industri merupakan proses membuat sesuatu yang tidak ada menjadi ada. Seiring dengan peningkatan populasi di dunia, kebutuhan akan barang juga meningkat. Hal ini memacu pertambahan jumlah dari industriindustri barang. Sebelum teknologi berkembang secara pesat seperti sekarang ini, industri masih sangat bergantung kepada manusia dalam pengoperasian mesin-mesin industri. Kebergantungan ini memiliki kelemahan pada proses di dalam industri yang sulit di lakukan oleh manusia. Masalah terjadi saat sebuah proses di dalam industri memerlukan respon yang cepat terhadap situasi atau perubahan yang terjadi di lapangan. Manusia dalam hal ini sebagai aktor utama sejatinya memiliki keterbatasan untuk melakukan kegiatan monitor, pengawasan dan mengontrol secara bersamaan. SCADA merupakan suatu solusi yang dibuat oleh manusia untuk mengatasi masalah-masalah tersebut yang terjadi di industri. 


\section{Metode Penelitian}

Perancangan dilakukan agar suatu sistem PLTS dapat di monitor dan di control melalui SCADA. Perancangan dapat dilihat pada gambar 1 sebagai berikut:

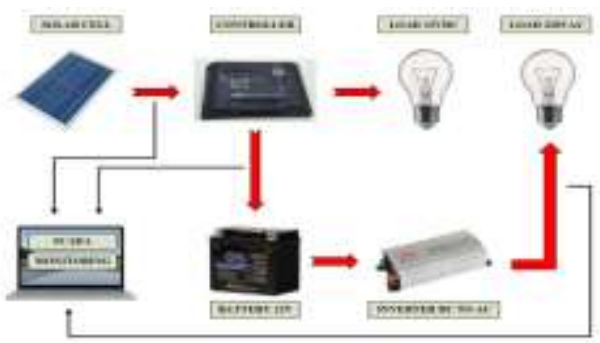

Gambar 1. Perancangan Sistem PLTS

Alat dan bahan digunakan akan disebutkan dan dijelaskan pada tabel 1 :

Tabel 1. Daftar Peralatan perancangan sistem PLTS

\begin{tabular}{|c|l|l|c|}
\hline No & \multicolumn{1}{|c|}{ Alat Utama } & \multicolumn{1}{|c|}{ Type } & Quantity \\
\hline 1 & Arduino Mega & ATmega 2560 & 1 Unit \\
\hline 2 & Sensor Tegangan DC & A08007 & 2 Unit \\
\hline 3 & Sensor Arus DC & ACS 712 30A & 2 Unit \\
\hline 4 & $\begin{array}{l}\text { Modul monitoring daya } \\
\text { multifungai AC }\end{array}$ & PZEM-004T & 1 Unit \\
\hline 5 & Solar Cell 20 WP & PolyCrystal & 1 Unit \\
\hline 6 & $\begin{array}{l}\text { PwM Controller Solar } \\
7\end{array}$ & 30A & 1 Unit \\
\hline 8 & $\begin{array}{l}\text { Inverter DC to AC } \\
300 W\end{array}$ & Dry battery & 1 Unit \\
\hline
\end{tabular}

\section{Hasil dan Pembahasan}

Untuk Pengujian hasil penelitian kita harus mengambil data perbandingan antara monitoring melalui software dan monitoring pengukuran manual, dimana setiap data kita bandingkan antara software dan pengambilan data manual lalu kita buat ke dalam tabel dan kita bandingkan selisih nya berapa persen. Pengujian hasil penelitian dapat kita buat dalam tabel sebagai berikut Pada pengujian ini dilakukan dengan pemasangan beban sebagai sebagaimana dalam table 2, sedangkan untuk hasil pengukuran pengujian tegangan ditunjukkan tabel 3 dan pengukuran arus ditunjukkan tabel 4 .

Tabel 2. Beban yang digunakan

\begin{tabular}{|c|l|c|c|}
\hline No & \multicolumn{1}{|c|}{ Beban } & $\begin{array}{c}\text { Tegangan } \\
(\mathrm{V})\end{array}$ & $\begin{array}{c}\text { Daya } \\
(\mathrm{W})\end{array}$ \\
\hline 1 & Lampu & $220 \mathrm{~V}$ & $7 \mathrm{~W}$ \\
\hline 2 & Kipas Angin & $220 \mathrm{~V}$ & $20 \mathrm{~W}$ \\
\hline
\end{tabular}

Tabel 3. Pengukuran Tegangan

\begin{tabular}{|c|l|c|c|c|}
\hline No & $\begin{array}{c}\text { Jenis } \\
\text { Penguluuran }\end{array}$ & $\begin{array}{c}\text { Tegangan } \\
\text { SolarCell } \\
\left(\mathrm{V}_{\mathrm{DC}}\right)\end{array}$ & $\begin{array}{c}\text { Tegangan } \\
\text { Battery } \\
\left(\mathrm{V}_{\mathrm{DC}}\right)\end{array}$ & $\begin{array}{c}\text { Tegangan } \\
\text { Beban } \\
\left(\mathrm{V}_{\mathrm{CC}}\right)\end{array}$ \\
\hline 1 & $\begin{array}{l}\text { Pengukuran } \\
\text { menggunakan } \\
\text { software }\end{array}$ & $12 \mathrm{~V}$ & $12,79 \mathrm{~V}$ & $220.9 \mathrm{~V}$ \\
\hline 2 & $\begin{array}{l}\text { Pengukuran } \\
\text { menggunakan } \\
\text { alat ukur }\end{array}$ & $12,45 \mathrm{~V}$ & $12,41 \mathrm{~V}$ & $217.8 \mathrm{~V}$ \\
\hline & Selisih & $\mathbf{0 , 4 5 \mathrm { V }}$ & $\mathbf{0 , 3 8 \mathrm { V }}$ & $\mathbf{3 . 1 \mathrm { V }}$ \\
\hline
\end{tabular}

Tabel 4. Pengukuran Arus

\begin{tabular}{|c|l|c|c|c|}
\hline No & $\begin{array}{c}\text { Jenis } \\
\text { Penguliuran }\end{array}$ & $\begin{array}{c}\text { Arus } \\
\text { SolarCell } \\
\left(\mathrm{A}_{\mathrm{Dc}}\right)\end{array}$ & $\begin{array}{c}\text { Arus } \\
\text { Battery } \\
\left(\mathrm{A}_{\mathrm{Dc}}\right)\end{array}$ & $\begin{array}{c}\text { Arus } \\
\text { Beban } \\
\left(\mathrm{A}_{\Delta \mathrm{C}}\right)\end{array}$ \\
\hline 1 & $\begin{array}{l}\text { Pengukuran } \\
\text { menggunakan } \\
\text { 5oftware }\end{array}$ & $0,4 \mathrm{~A}$ & $2,14 \mathrm{~A}$ & $0.14 \mathrm{~A}$ \\
\hline 2 & $\begin{array}{l}\text { Pengukuran } \\
\text { menggunakan } \\
\text { alat ukur }\end{array}$ & $0,2 \mathrm{~A}$ & $2,1 \mathrm{~A}$ & $0.1 \mathrm{~A}$ \\
\hline & \multicolumn{1}{|c|}{ Selisih } & $\mathbf{0 , 2 \mathrm { A }}$ & $\mathbf{0 , 4 \mathrm { A }}$ & $\mathbf{0 . 4 \mathrm { A }}$ \\
\hline
\end{tabular}

\section{Kesimpulan}

Monitoring PLTS bisa dilakukan menggunakan software sehingga apabila diterapkan dilapangan maka akan mengurangi pekerjaan operator dengan cara mencatat ke lokasi tempat langsung.Untuk hasil pengukuran hasilnya berbeda dengan pengukuran menggunakan alat ukur dikarenakan Class alat ukur setiap merk berbeda-beda. 


\section{Daftar Pustaka}

Agfianto. 2009. SCADA, (Online), (http://agfi.staff.ugm.ac.id/blog/index.php/2 009/03/tutorialscada-1-apamanfaat-scadabagi-anda).

Assisten, Tim. 2010. 8 Th Basic Automation Training Module. Bandung : Laboratorium Sistem Produksi \& Automasi IT Telkom.

Automation. 2010. ARC Advisory Group , (Online), (http://www.automation.com/content/arcad visory-electric-power-scadamarket-to experience-resurgence-in-growth).

Groover, M.P., 2001. Otomasi, Sistem Produksi, dan Computer-Integrated Manufacturing. Surabaya: Guna Widya.

Gordon, C., Baily, D., Wright, E., 2003, "Practical SCADA Modern Protocol," IDC Technologies, Australia.

"Vijeo Citect Training Manual," Schneider Electric, Australia, 2009.

Prasetia, Widodo, 2004, “Teori dan Praktek Interfacing Port Parallel dan Port Serial Komputer dengan Visual Basic 6.0," Penerbit Andi, Yogyakarta.

"Quickstart Tutorial Vijeo Citect v7.0," Schneider Electric, Australia, 2009.

M. Rizal Fachri, Ira Devi Sara, dan Yuwaldi Away (2015), Pemantauan Parameter Panel Surya Berbasis Arduino secara Real Time. Jurnal Rekayasa Elektrika Vol. 11,No. 4, Agustus 2015, hal. 123-128 